\title{
EVALUASI PENGGUNAAN PESTISIDA PADA PETANI BAWANG MERAH DI DESA WOMBO MPANAU KECAMATAN TANANTOVEA KABUPATEN DONGGALA
}

\section{EVALUATION OF THE USE OF PESTICIDES IN RED ONION FARMERS IN WOMBO MPANAU VILLAGE, TANANTOVEA SUB DISTRICT DONGGALA DISTRICT}

\author{
Tri Satyani ${ }^{1}, \operatorname{Arfan}^{1 *}$, Sayani $^{1}$ \\ ${ }^{1}$ Program Studi Agroteknologi, Fakultas Pertanian Universitas Alkhairaat Palu, \\ Jl. Diponegoro No. 39 Palu 94221, Indonesia
}

\begin{abstract}
ABSTRAK
Penelitian ini bertujuan untuk mempelajari dan mengetahui perilaku petani dalam penggunaan pestisida pada tanaman bawang merah di Desa Wombo Mpanau Kecamatan Tanantovea. Penelitian ini menggunakan metode acak sederhana (simple random samping). Data yang diperoleh dikumpulkan, diolah lalu dianalisis. Analisis dilakukan untuk mengetahui frekuensi data pada masing-masing variabel. Data primer yang diperoleh melalui wawancara dianalisis untuk memberikan gambaran ringkas kelompok data dalam satu tabel frekuensi. Jenis OPT yang menyerang tanaman bawang merah di Desa Wombo Mpanau adalah ulat daun, lalat daun, trips, embun tepung, dan layu fusarium. Cara pengendalian OPT yang paling banyak dilakukan adalah penggunaan pestisida kimia, yakni mencapai $70 \%$ responden. Pengetahuan petani terhadap waktu aplikasi pestisida tergolong baik, yakni $100 \%$ responden mengaplikasikan pestisida saat terdapat gejala serangan dan jika pengendalian lain tidak mampu mengatasi serangan OPT. Pengetahuan petani terhadap penggunaan dosis pestisida tergolong baik, yakni $100 \%$ responden menggunakan dosis sesuai anjuran yang tercantum pada kemasan. Tindakan petani pada saat aplikasi pestisida pada umumnya adalah tidak melakukan pencampuran pestisida. Mayoritas responden telah melakukan tindakan yang benar dalam hal penyimpanan alat semrot dan pestisida pada tempat khusus. Namun disisi lain kesadaran petani masih rendah, karena masih banyak petani yang mencuci alat semprot di sungai atau parit.
\end{abstract}

Katakunci: evaluasi, penggunaan pestisida, petani bawang merah

\section{ABSTRACT}

This study aims to study and determine the behavior of farmers in the use of pesticides on shallots in Wombo Mpanau Village, Tanantovea District. This study uses a simple random method. The data obtained is collected, processed and analyzed. Analysis was carried out to determine the frequency of data in each variable. Primary data obtained through interviews were analyzed to provide a concise picture of groups of data in one frequency table. Types of pests that attack onion in Wombo Mpanau Village are leaf caterpillars, leaf flies, trips, flour dew, and fusarium wilt. The most widely used pest control method is the use of chemical pesticides, which reaches $70 \%$ of respondents. The knowledge of farmers on the application of pesticides is relatively good, namely $100 \%$ of respondents apply pesticides when there are symptoms of attack and if other controls are unable to overcome the pest attack. Knowledge of farmers on the use of doses of pesticides is relatively good, namely $100 \%$ of respondents use the dosage according to the recommendations listed on the packaging. The actions of farmers when applying pesticides in general are not mixing pesticides. The majority of respondents have taken the right action in terms of storing semrot and pesticides in a special place. But on the other hand the awareness of farmers is still low, because there are still many farmers who wash sprayers in rivers or ditches.

Keywords: evaluation, use of pesticides, red onion farmers

\footnotetext{
${ }^{*}$ Penulis Korespondensi

E-mail: arfanilmu@gmail.com

Telp: +62-85228976417
} 


\section{Jurnal Agrotech 9 (1) 26-32}

\section{Pendahuluan}

Komoditas sektor pertanian terdiri dari sektor tanaman pangan dan sektor tanaman hortikultura. Tanaman pangan merupakan komoditas utama untuk kehidupan manusia, yaitu sebagai bahan makanan pokok penyedia kebutuhan karbohidrat, vitamin dan mineral. Menurut Rositasari (2006), tanaman hortikultura mencakup sayuran, buah-buahan, tanaman hias (florikutura), dan tanaman obat-obatan (biofarmaka). Sayuran merupakan komoditas subsektor hortikultura yang sangat penting bagi kehidupan manusia. Selain bahan makanan, kandungan gizi yang terdapat di dalamnya sangat diperlukan dalam proses pertumbuhan dan perkembangan manusia.

Produksi sayuran dan tanaman pangan sangat dipengaruhi oleh adanya serangan hama dan penyakit tanaman. Menurut Rambe (2012), hasil produksi sayuran dipengaruhi oleh musim dan organisme pengganggu tanaman. Faktor pembatas produksi sayuran yang paling penting adalah serangan hama dan penyakit tanaman. Adanya faktor pembatas tersebut dapat menyebabkan perubahan hasil produksi yang berdampak terhadap suplai sayuran. Hal yang sama terjadi juga pada tanaman pangan, kehilangan hasil produksi selalu disebabkan oleh hama dan penyakit tanaman, gulma, dan tekanan yang ekstrim faktor abiotik (Sinaga 2009).

Petani sebagai produsen utama komoditi pangan harus terus memiliki motivasi dan sumber daya untuk terus menghasilkan komoditi pertanian, khususnya tanaman pangan yang memenuhi skala kuantitas dan kualitas guna memenuhi kebutuhan dalam negeri sehingga tercipta kemandirian pangan. Hal itu didasarkan bahwa pangan merupakan segala sesuatu yang berasal dari sumber hayati dan air, baik yang diolah maupun tidak diolah, yang diperuntukkan sebagai makanan atau minuman bagi konsumsi manusia (UU No 7 1996). Oleh karena itu, diperlukan upaya untuk meningkatkan kuantitas dan kualitas pangan dari kemungkinan adanya residu yang membahayakan kesehatan manusia. Hal ini dikarenakan petani di Indonesia umumnya masih mengandalkan pestisida sintetik untuk mengatasi organisme pengganggu tanaman, seperti hama dan penyakit tanaman (Taufiq, 2004). Alasan petani cenderung memilih pestisida sintetik karena hasilnya terlihat lebih cepat. Namun penggunaan pestisida sintetik secara terus menerus dapat menyebabkan residu pada hasil pertanian, resistensi hama, resurjensi
e-ISSN : 2621-7236

p-ISSN : 1858-134X

hama, munculnya hama sekunder, dan pencemaran lingkungan (Tarigan, 2002). Oleh karena itu, penerapan praktik pertanian yang baik sangat dibutuhkan.

Praktik pertanian yang baik, salah satunya dengan penerapan pengendalian hama terpadu (PHT) yang menggunakan pestisida secara rasional dalam proses produksi pertanian. Oleh karena itu, diperlukan pengetahuan tentang persepsi petani dalam penggunaan pestisida. Hasil penelitian Kusnaya (2014) mengemukakan bahwa persepsi petani tanaman pangan dan sayuran terhadap penggunaan pestisida dipengaruhi oleh beberapa faktor antara lain tingkat pendidikan, pangsa pasar, jenis tanaman, dan sumber informasi pemilihan jenis pestisida. Persepsi yang dimaksud adalah bagaimana tingkat pengetahuan, sikap dan tindakan petani dalam menggunakan pestisida pada tanaman khususnya tanaman bawang merah. Berdasarkan beberapa uraian tersebut di atas, maka dilakukan penelitian ini yang berjudul Evaluasi Penggunaan Pestisida pada petani bawang merah di Desa Wombo Mpanau Kecamatan Tanantovea Kabupaten Donggala.

\section{Metode Penelitian}

Penelitian ini dilaksanakan di Desa Wombo Mpanau Kecamatan Tanantovea Kabupaten Donggala Propinsi Sulawesi Tengah. Penelitian ini dilaksanakan dengan menggunakan metode survey. Penentuan lokasi penelitian dilakukan secara sengaja (Purposive Sampling) berdasarkan observasi sebelumnya bahwa daerah ini mayoritas penduduknya berprofesi sebagai petani. Salah satu komoditi yang banyak dikembangkan adalah bawang merah. Penentuan responden dilakukan dengan menggunakan metode Multistage Random Sampling melalui tahapan sebagai berikut:

a. Menentukan lokasi atau dusun yang dapat mewakili dari seluruh wilayah Desa Wombo Mpanau.

b. Menentukan kelompok tani pada setiap dusun yang dijadikan sampel, yakni terdiri dari dua kelompok tani.

c. Menentukan lima responden dari setiap kelompok tani, sehingga diperoleh total sampel sebanyak 10 petani responden.

Penelitian ini dilaksanakan melalui beberapa tahap sebagai berikut:

a. Observasi lokasi penelitian yang bertujuan untuk mengetahui gambaran umum lokasi penelitian di Desa Wombo Mpanau, 


\section{Jurnal Agrotech 9 (1) 26-32}

khususnya lokasi budidaya tanaman bawang merah. Informasi ini diperoleh dari penyuluh pertanian, pemerintah Desa Wombo Mpanau, dan pengamatan langsung di lapangan.

b. Merencanakan waktu dan tempat pelaksanaan wawancara dengan cara membuat perjanjian terlebih dahulu dengan petani responden.

c. Persiapan lembar kuisioner yang bertujuan untuk merangkum hasil wawancara dengan petani responden. Kuisioner dibuat dengan bahasa yang mudah dimengerti dengan bentuk pertanyaan-pertanyaan yang berkaitan dengan judul penelitian.

d. Wawancara secara mendalam dengan petani responden dan pengisian kuisioner. Kegiatan ini dilakukan secara bersamaan, dimana peneliti secara aktif berdiskusi dengan responden tentang item-item dalam lembar kuisioner.

e. Selain melalui wawancara, informasi juga diperoleh melalui fakta yang dibuat dengan cara mendokumentasikan objek penelitian. Dokumentasi juga diperlukan untuk menyatakan kebenaran atau keabsahan penelitian ini.

Data yang diperoleh dalam penelitian ini bersumber dari data primer dan data sekunder. Data primer diperoleh dari hasil wawancara dengan responden secara langsung yang dimuat dalam lembar kuisioner. Data sekunder diperoleh dari Dinas Pertanian dan Kehutanan Kabupaten Donggala, Badan Pusat Statistik (BPS) Kabupaten Donggala, Balai Penyuluhan Pertanian Peternakan dan Kehutanan (BP3K) Wilayah Kecamatan Tanantovea, Kepala Desa, Gapoktan, Artikel, Internet serta sumber-sumber lain yang menunjang penelitian.

Data primer yang diperoleh melalui wawancara dianalisis dan dijabarkan secara deskripsi, selanjutnya disajikan dalam bentuk tabel distribusi frekuensi. Hal-hal yang diamati adalah karaktersitik responden dan evaluasi penggunaan pestisida yang meliputi pengamatan OPT yang menyerang, jenis pengendalian yang digunakan, pengalaman menggunakan pestisida, waktu aplikasi, dosis, tindakan saat aplikasi, dan tindakan terhadap aspek lingkungan.

\section{Hasil dan Pembahasan}

\section{Karaktersitik Responden}

Data karakteristik responden petani bawang merah di Desa Wombo Mpanau memiliki karakteristik yang beragam, karakter-
e-ISSN : 2621-7236

p-ISSN : 1858-134X

karakter tersebut dapat membedakan tipe perilaku petani pada situasi tertentu. Karakteristik yang diamati dalam penelitian ini adalah umur dan pendidikan.

Umur sangat berpengaruh terhadap produktivitas tenaga kerja. Dalam batasbatas tertentu, semakin bertambah umur seseorang maka tenaga kerja yang dimiliki akan semakin produktif, dan setelah umur tertentu produktivitas tersebut akan menurun. Menurut BPS (2015), berdasarkan komposisi penduduk, umur dikelompokkan menjadi 3 yaitu umur 0-14 tahun dianggap sebagai kelompok penduduk belum produktif, kelompok penduduk umur 15-64 tahun sebagai kelompok produktif dan kelompok umur 65 tahun ke atas sebagai kelompok penduduk yang tidak lagi produktif. Hasil penelitian menunjukkan bahwa umur petani responden berkisar antar 38-56 tahun. Hal ini (Lampiran 2) menunjukkan bahwa seluruh petani responden di Desa Wombo Mpanau berada pada kategori umur produktif. Umur responden terkait dengan adanya inovasi, seseorang pada umur non produktif akan cenderung sulit menerima inovasi, sebaliknya seseorang dengan umur produktif akan lebih mudah dan cepat menerima inovasi. Hal ini sesuai dengan pendapat Soekartawi (2005) bahwa makin muda petani biasanya mempunyai semangat untuk ingin tahu apa yang belum mereka ketahui, sehingga mereka berusaha untuk lebih cepat melakukan adopsi inovasi walaupun biasanya mereka masih belum berpengalaman dalam soal adopsi inovasi tersebut.

Pendidikan pada hakekatnya merupakan usaha sadar manusia untuk mengembangkan kepribadian dan meningkatkan kemampuan di dalam dan di luar sekolah yang berlangsung seumur hidup. Semakin tinggi tingkat pendidikan penduduk/masyarakat, maka akan semakin tinggi pula kualitas penduduk (sumber daya manusia). Tingkat pendidikan sangat terkait dengan tingkat kemampuan mengadopsi inovasi teknologi. Diharapkan semakin tinggi tingkat pendidikan maka proses alih teknologi akan berjalan lebih cepat dan lebih baik.

Hasil penelitian menunjukkan bahwa pendidikan petani responden tergolong dalam kategori rendah karena mayoritas (60\%) responden hanya sampai tingkat pendidikan SD. Hasil ini menunjukkan bahwa petani cenderung kurang memiliki pengetahuan yang cukup untuk dapat memahami permasalahan mereka dan kurang tepat dalam menyelesaikan permasalahan yang dihadapi untuk dapat mencapai tujuan yang diharapkan. Menurut Saridewi \& Siregar (2010), 


\section{Jurnal Agrotech 9 (1) 26-32}

tingkat pendidikan seseorang dapat mengubah pola pikir, daya penalaran yang lebih baik, sehingga makin lama seseorang mengenyam pendidikan akan semakin rasional. Lebih lanjut dijelaskan bahwa mereka yang berpendidikan tinggi adalah relatif lebih cepat dalam melaksanakan adopsi teknologi. Begitu pula sebaliknya, mereka yang berpendidikan rendah agak sulit untuk melaksanakan adopsi inovasi dengan cepat.

\section{Evaluasi Penggunaan Pestisida}

Organisme pengganggu tanaman yang menyerang

Hasil penelitian menunjukkan bahwa terdapat lima jenis OPT yang menyerang tanaman bawang merah di Desa Wombo Mpanau.

Tabel 1. Jenis OPT yang menyerang tanaman bawang merah

\begin{tabular}{llcc}
\hline $\mathrm{N}$ & Jenis OPT & $\begin{array}{c}\text { Jumlah } \\
\text { responden } \\
\text { (org) }\end{array}$ & $\begin{array}{c}\text { Persentase } \\
(\%)\end{array}$ \\
\hline 1. & Ulat daun & 7 & 70 \\
2. & Lalat daun & 3 & 30 \\
3. & Trips & 2 & 20 \\
4. & Embun tepung & 2 & 20 \\
5. & Layu fusarium & 1 & 10 \\
\hline
\end{tabular}

Sumber: Data primer setelah diolah

Hasil penelitian (Tabel 1) menunjukkan bahwa hama ulat daun merupakan jenis hama yang dominan menyerang tanaman bawang merah di Desa Wombo Mpanau, yakni mencapai $70 \%$ responden, sementara hama lalat daun, hama trips, penyakit embun tepung dan layu fusarium merupakan OPT yang tergolong sedikit menyerang tanaman bawang merah, yakni hanya mencapai $10-30 \%$ responden.

Serangan hama ulat daun dapat dikatakan cukup merata di Desa Wombo Mpanau. Meratanya serangan hama ulat daun diduga disebabkan karena kondisi cuaca yang panas. Kondis cuaca panas dapat memicu perkembangan populasi hama. Nugroho (2013) menerangkan bahwa pada kondisi kering dan suhu tinggi, metabolisme serangga hama meningkat sehingga memperpendek siklus hidup. Akibatnya jumlah telur yang dihasilkan meningkat dan akhirnya mendorong peningkatan populasi. Oleh karena itu, intensitas serangan ulat grayak pada pertanaman bawang merah musim kemarau umumnya lebih tinggi dibanding pada musim hujan.
e-ISSN : 2621-7236

p-ISSN : 1858-134X

Pengendalian OPT

Hasil penelitian menunjukkan bahwa terdapat dua cara pengendalian OPT yang digunakan oleh petani bawang merah di Desa Wombo Mpanau.

Tabel 2. Cara pengendalian organsime pengganggu tanaman bawang merah

\begin{tabular}{llcc}
\hline No. & $\begin{array}{c}\text { Cara } \\
\text { pengendalian }\end{array}$ & $\begin{array}{c}\text { Jumlah } \\
\text { responden } \\
\text { (org) }\end{array}$ & $\begin{array}{c}\text { Persentase } \\
(\%)\end{array}$ \\
\hline 1. & $\begin{array}{l}\text { Pestisida } \\
\text { kimia } \\
\text { Secara hayati }\end{array}$ & 7 & 70 \\
& Jumlah & 10 & 30 \\
\hline
\end{tabular}

Sumber: Data primer setelah diolah

Hasil penelitian (Tabel 2) menunjukkan bahwa $70 \%$ responden melakukan pengendalian menggunakan pestisida kimia dan 30\% lainnya dengan cara hayati. Hal ini menunjukkan bahwa cara pengendalian OPT yang paling banyak digunakan oleh petani bawang merah di Desa Wombo Mpanau ialah penggunaan pestisida kimia.

Penggunaan pestisida kimia masih merupakan pilihan utama petani sampai saat ini, karena dinilai lebih efektif dan efisien untuk mengendalikan OPT. Hal ini juga terjadi di Desa Wombo Mpanau, dimana hasil penelitian menunjukkan $70 \%$ responden menggunakan pestisida kimia tersebut. Namun demikian, ada beberapa petani yang telah menggunakan pengendalian secara hayati, yakni dengan memanfaatkan mahluk hidup lain untuk mengendalikan hama. Hal ini disebabkan karena timbulnya kesadaran petani tentang bahaya dari penggunaan pestisida kimia.

Pengalaman menggunakan pestisida

Hasil penelitian menunjukkan bahwa pengalaman petani responden menggunakan pestisida cukup beragam, yakni mulai 2 tahun sampai dengan 20 tahun.

Tabel 3. Pengalaman petani bawang merah dalam menggunakan pestisida

\begin{tabular}{cccc}
\hline $\mathrm{N}$ & $\begin{array}{c}\text { Lama } \\
\text { menggunakan } \\
\text { pestisida } \\
\text { (tahun) }\end{array}$ & $\begin{array}{c}\text { Jumlah } \\
\text { responden } \\
\text { (org) }\end{array}$ & $\begin{array}{c}\text { Persentase } \\
(\%)\end{array}$ \\
\hline 1. & $1-10$ & 5 & 50 \\
2. & $11-20$ & 5 & 50 \\
\hline & Jumlah & 10 & 100 \\
\hline
\end{tabular}

Sumber: Data primer setelah diolah 


\section{Jurnal Agrotech 9 (1) 26-32}

Hasil penelitian (Tabel 3) menunjukkan bahwa 50\% responden memiliki pengalaman menggunakan pestisida 1 - 5 tahun atau memiliki pengalaman yang masih sedikit dan 50\% responden memiliki penglaman 16 - 20 tahun atau memiliki pengalaman yang cukup banyak dalam hal penggunaan pestisida.

Pengalaman seseorang merupakan salah satu parameter yang membentuk tingkat sosial ekonomi seseorang, dengan semakin lama seseorang berprofesi pada bidang tertentu maka orang tersebut dianggap lebih mengetahui dan menguasai bidang tersebut. Milton (1961) dalam Panurat (2014) menyatakan bahwa semakin banyak pengalaman yang diperoleh oleh petani, maka minat mereka terhadap usahatani padi sawah semkin tinggi, dengan banyaknya pengalaman yang tekah mereka lalui, maka banyak cara yang dapat mereka lakukan untuk menaikkan produksi panen.

Pengetahuan waktu aplikasi pestisida

Waktu aplikasi yang dikategorikan tepat pada penelitian ini adalah saat terlihat gejala serangan pada tanaman dan ketika pengendalian lain tidak mampu mengatasi OPT yang menyerang, sementara waktu aplikasi yang tidak tepat adalah sebelum adanya serangan dan ketika OPT telah menyebar.

Tabel 4. Pengetahuan petani tentang waktu aplikasi pestisida

\begin{tabular}{lcc}
\hline Waktu Aplikasi & Jumlah (orang) & $\begin{array}{c}\text { Persentase } \\
(\%)\end{array}$ \\
\hline Tepat & 10 & 100,0 \\
Tidak tepat & 0 & 0 \\
\hline Total & 10 & 100,0 \\
\hline Sumber: Data primer setelah diolah &
\end{tabular}

Hasil penelitian (Tabel 4) menunjukkan bahwa terdapat $10(100 \%)$ responden yang menggunakan pestisida pada waktu yang tepat. Hasil ini menunjukkan bahwa mayoritas petani di Desa Wombo Mpanau mengaplikasikan pestisida pada waktu yang tepat, sehingga dapat dikatakan bahwa pengetahuan petani tentang waktu aplikasi pestisida sudah baik. Hal ini diduga disebabkan selain karena informasi dari penyuluh, juga karena petani responden telah banyak belajar dari pengalaman.

Pengendalian OPT menggunakan pestisida pada saat munculnya gejala serangan atau jika pengendalian lain tidak lagi mampu mengendalikan OPT merupakan cara yang baik untuk menjaga keseimbangan ekosistem dan kelestarian lingkungan, karena pada saat tersebut intensitas serangan masih tergolong rendah dan
e-ISSN : 2621-7236

p-ISSN : 1858-134X

pada umumnya belum mencapai ambang ekonomi. Penggunaan pestisida pada saat hama telah menyebar dinyatakan kurang tepat, karena pada saat tersebut sangat memungkinkan OPT sangat sulit dikendalikan sehingga dapat menyebabkan penurunan produksi dan pada akhirnya mengakibatkan kerugian secara ekonomi. Demikian pula pengendalian yang dilakukan sebelum adanya serangan, hal ini akan menjadi tidak efisien karena menyebabkan kerugian akibat pengadaan sarana produksi (pestisida) dan memungkinkan terjadinya pencemaran lingkungan akibat dari penggunaan bahan kimia sintetis. Menurut Djafaruddin (2007) bahwa dalam pemakaian zat kimia atau pestisida khususnya, maka yang perlu diperhatikan untuk meningkatkan efektivitas atau dampak hasilnya yang dikehendaki adalah harus melakukannya secara tepat, yaitu tepat dosis atau konsentrasi, tepat waktu dan tepat sasarannya.

Pengetahuan dosis pestisida

Pengetahuan tentang dosis dalam hal ini adalah penggunaan pestisida dengan dosis sesuai anjuran atau tidak sesuai anjuran.

Tabel 5. Pengetahuan petani tentang penggunaan dosis pestisida

\begin{tabular}{lcc}
\hline Penggunaan dosis & $\begin{array}{c}\text { Jumlah } \\
\text { (orang) }\end{array}$ & $\begin{array}{c}\text { Persentase } \\
(\%)\end{array}$ \\
\hline Sesuai anjuran & 10 & 100,0 \\
Tidak sesuai anjuran & 0 & 0 \\
\hline Total & 10 & 100,0 \\
\hline
\end{tabular}

Sumber: Data primer setelah diolah

Hasil penelitian (Tabel 5) menunjukkan bahwa terdapat $10(100 \%)$ responden yang menggunakan pestisida dengan dosis sesuai anjuran. Hal ini menunjukkan bahwa mayoritas petani di Desa Wombo Mpanau telah menggunakan pestisida dengan dosis sesuai anjuran yang tercantum pada kemasan, sehingga dapat dikatakan bahwa rata-rata pengetahuan petani tentang dosis pestisida sudah baik. Hal ini diduga disebabkan karena petani responden ratarata berumur 40-50 tahun atau dapat dikatakan telah memiliki cukup pengalaman dalam berusahatani, sehingga sudah banyak pengetahuan tentang dampak dari penggunaan pestisida yang tidak sesuai anjuran.

Pengetahuan tentang dosis sangat dibutuhkan oleh petani dalam hal penggunaan pestisida, sebab penggunaan dosis yang berlebihan justru akan menyebabkan terganggunya keseimbangan ekosistem dan kesehatan manusia. Menurut Wahyuni (2010), bahwa dampak negatif penggunaan pestisida 
telah banyak dilaporkan dalam berbagai penelitian. Dampak tersebut dapat berupa ketidak-stabilan ekosistem, adanya residu pada hasil panen dan bahan olahannya, pencemaran lingkungan dan keracunan bahkan kematian pada manusia. Sinulingga (2005) menambahkan bahwa pestisida juga dapat menimbulkan

Tabel 6. Tindakan petani pada saat aplikasi pestisida

\begin{tabular}{ccccc}
\multicolumn{2}{l}{ Tabel 6. Tindakan petani pada saat aplikasi pestisida } & \multicolumn{4}{l}{} \\
\cline { 2 - 5 } Uraian & Jumlah & Persentase & Jumlah & Persentase \\
\cline { 2 - 5 } & Ya & $\%$ & Tdk & $\%$ \\
\hline Mencampur pestisida & 1 & 10 & 9 & 90 \\
Menggunakan masker & 5 & 50 & 5 & 50 \\
\hline
\end{tabular}

resistensi hama, ledakan hama, timbulnya hama sekunder.

Tindakan saat aplikasi pestisida

Hasil penelitian menunjukkan bahwa terdapat dua jenis tindakan yang dilakukan pada saat aplikasi pestisida. Adapun distribusinya dapat dilihat pada Tabel 6 .
Hasil penelitian (Tabel 6) menunjukkan bahwa terdapat $9(90 \%)$ responden yang tidak melakukan pencampuran pestisida. Hal ini menunjukkan bahwa sebagian besar petani di Desa Wombo Mpanau tidak mencampur pestisida dengan jenis lain dalam satu kali aplikasi. Selain itu, hasil penelitian juga menunjukkan bahwa terdapat $5(50 \%)$ responden yang menggunakan masker saat aplikasi pestisida, sementara $5(50 \%)$ lainnya tidak menggunakannya. Hal ini menunjukkan bahwa sebagian petani di Desa Wombo Mpanau tidak menggunakan masker pada saat aplikasi pestisida, sehingga dapat dikatakan bahwa kesadaran petani dalam hal penggunaan masker rata-rata masih rendah.

Pencemaran dan keracunan pestisida umumnya terjadi akibat kelalaian manusia dalam penggunaannya, karena toksisitas atau daya racun

Tabel 9. Tindakan petani terhadap aspek lingkungan

\begin{tabular}{lcccc}
\hline \multirow{2}{*}{ Uraian } & Jumlah & Persentase & Jumlah & Persentase \\
\cline { 2 - 5 } & Ya & $\%$ & Tdk & $\%$ \\
\hline $\begin{array}{l}\text { Mencuci alat semprot di sungai atau parit } \\
\begin{array}{l}\text { Memiliki tempat penyimpanan khusus alat dan } \\
\text { pestisida }\end{array}\end{array}$ & 5 & 50 & 5 & 50 \\
\hline
\end{tabular}

Sumber: Data primer setelah diolah

Hasil penelitian (Tabel 9) menunjukkan bahwa terdapat $5(50 \%)$ responden yang mencuci alat semprot di sungai atau parit dan $10(100 \%)$ responden memiliki tempat penyimpanan khusus untuk peralatan dan pestisida. Hal ini menunjukkan bahwa mayoritas petani di Desa Wombo Mpanau telah melakukan tindakan yang benar dalam hal penyimpanan alat semrot dan pestisida pada tempat khusus. Namun disisi lain kesadaran petani masih rendah, karena masih banyak petani yang mencuci alat semprot di sungai atau parit. Salah satu tindakan yang penting untuk diperhatikan dalam hal menjaga kesehatan dan keselamatan adalah menyimpan bahan kimia (pestisida), perlengkapan pelindung, pestisida adalah sifat bawaan yang menggambarkan potensi pestisida untuk membunuh secara langsung pada hewan dan manusia. Menurut Yuantari (2009), bahwa penggunaan pestisida yang tidak terkendali akan menimbulkan bermacam-macam masalah kesehatan dan pencemaran lingkungan. Wahyuni (2010) menambahkan bahwa hal ini juga diperparah dengan perilaku petani dalam menggunakan dan penanganan pestisida yang masih belum arif dan belum ramah lingkungan.

Tindakan petani terhadap aspek lingkungan

Hasil penelitian menunjukkan bahwa terdapat dua jenis tindakan yang dilakukan yang berdampak pada lingkungan. Adapun distribusinya dapat dilihat pada Tabel 9 .

dan peralatan semprot di tempat aman yang jauh dari bahan makan dan jangkauan anak-anak.

Mencuci alat semprot dekat sumber atau saluran air dapat merusak makhluk hidup yang ada di air. Selain itu pestisida dapat menyuburkan ganggang yang ada di sungai. Apabila ganggang yang ada di sungai menjadi subur maka cahaya matahari akan sulit masuk ke dalam sungai. Hal ini dapat menyebabkan makhluk hidup yang ada di air tidak mendapat cahaya misalnya fitoplankton. Bila fitoplankton tidak mendapatkan cahaya maka tidak akan bisa berfotosintesis dan tidak dapat lagi menghasilkan makanan untuk hewan-hewan yang ada di dalam air. Wudianto (2010) menjelaskan bahwa salah 


\section{Jurnal Ogrotech 9 (1) 26-32}

satu hal yang perlu diperhatikan dalam hal penggunaan pestisida adalah mencuci alat semprot (tangki) segera setalah digunakan dan air bekas cucian sebaiknya dibuang ke lokasi yang jauh dari sumber air dan sungai.

\section{Kesimpulan dan Saran}

\section{Kesimpulan}

1. Jenis OPT yang menyerang tanaman bawang merah di Desa Wombo Mpanau adalah ulat daun, lalat daun, trips, embun tepung, dan layu fusarium.

2. Cara pengendalian OPT yang paling banyak dilakukan adalah penggunaan pestisida kimia, yakni mencapai $70 \%$ responden.

3. Pengetahuan petani terhadap waktu aplikasi pestisida tergolong baik, yakni 100\% responden mengaplikasikan pestisida saat terdapat gejala serangan dan jika pengendalian lain tidak mampu mengatasi serangan OPT.

4. Pengetahuan petani terhadap penggunaan dosis pestisida tergolong baik, yakni $100 \%$ responden menggunakan dosis sesuai anjuran yang tercantum pada kemasan.

5. Mayoritas responden telah melakukan tindakan yang benar dalam hal penyimpanan alat semrot dan pestisida pada tempat khusus. Namun disisi lain kesadaran petani masih rendah, karena masih banyak petani yang mencuci alat semprot di sungai atau parit.

\section{Saran}

Perlu adanya sosialisasi di lokasi penelitian terutama untuk meningkatkan pengetahuan tentang tindakan petani dalam menggunakan pestisida, agar dampak negatif dari penggunaan pestisida yang tidak bijaksana dapat diminimalisir.

\section{Daftar Pustaka}

BPS, 2015. Sosial dan Kependudukan (Deskripsi Angka Beban Tanggungan). Badan Pusat Statistik Republik Indonesia, Jakarta

Djafaruddin, 2007. Dasar-dasar Perlindungan Tanaman. Bumi Aksara, Jakarta

Kusnaya, A.A., 2004. Persepsi Petani Sayuran dan Tanaman Pangan pada Penggunaan Pestisida untuk Produksi Produk Pertanian Sehat di Desa Lingkar Kampus IPB. [skripsi]. Departemen Proteksi Tanaman, Fakultas Pertanian, IPB, Bogor.

Rambe AY. 2012. Pengetahuan, Sikap, Dan Tindakan Petani Sayuran Di Kecamatan
e-ISSN : 2621-7236

p-ISSN : 1858-134X

Cibungbulang, Kabupaten Bogor Dalam Mengendalikan Hama Dan Penyakit Tanaman [skripsi]. Institut Pertanian Bogor.

Rositasari WE. 2006. Analisis Strategi Pemasaran Tanaman Hias Daun Dalam Pemanfaatan Sebagai Daun Potong Pada Pesona Daun Hias Asri [skripsi]. Institut Pertanian Bogor

Saridewi, T.R. \& A.N. Siregar, 2010. Hubungan Antara Peran Penyuluh dan Adopsi Teknologi oleh Petani terhadap Peningkatan Produksi Padi di Kabupaten Tasikmalaya. Jurnal Penyuluhan Pertanian Vol. 5 No. 1

Sinaga MS. 2009. Bioteknologi dalam pertanian berkelanjutan: mencapai ketahanan, keamanan dan kedaulatan pangan. Di dalam: Peranan IPTEKS dalam Pengelolaan Pangan, Energi, SDM, dan Lingkungan yang Berkelanjutan. IPB Press, hlm 106-113

Sinulingga, K. 2005. Analisis Residu Piretroid pada Sampel Wortel di Daerah Sentra Produksi Kab. Karo. Jurnal Sistem Teknik Industri 6: 64-68

Soekartawi, 2005. Agribisnis Teori dan Aplikasinya. Raja Grafindo Persada, Jakarta

Tarigan SA. 2002. Pengetahuan, Sikap, Dan Tindakan Petani Dalam Pelaksanaan PHT Pada Tanaman Kubis Di Kecamatan Pangalengan, Bandung, Jawa Barat [skripsi]. Institut Pertanian Bogor.

Wahyuni, S. 2010. Perilaku Petani Bawang Merah dalam Penggunaan dan Penanganan Pestisida Serta Dampaknya Terhadap Lingkungan. Tesis. Program Magister Ilmu Lingkungan. Univerisitas Diponegoro, Semarang

Wudianto, R., 2005. Petunjuk Penggunaan Pestisida. Penerbit Penebar Swadaya. Jakarta

Yuantari, M.G.C. 2009. Studi Ekonomi Lingkungan Penggunaan Pestisida dan Dampaknya pada Kesehatan Petani di Area Pertanian Hortikultura Desa Sumber Rejo Kecamatan Ngablak Kabupaten Magelang Jawa Tengah. Thesis. Universitas Diponegoro, Semarang. 